\section{Editorial Pointers}

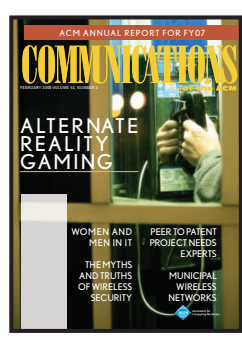

Alternate REAlity gaming (ARG) IS a RELATIVELy new genre of collaborative entertainment that combines online information and puzzles with real-world events. Known for their elaborate scavenger hunts, ARGs attract players into interactive plots that often blur the distinction between cyberspace and public space; online cues lead players to real-world clues with the goal of finding the ending to the story-an ending they ultimately create themselves.

One recent example of ARGs that generated media interest was the cross-media game "I Love Bees," or ILB. Its intricate and evolving storyline prompted a diverse group of players to follow cyber clues that led to ringing pay phones (and clues) across the U.S. and the U.K.

The ILB model posed some unique design challenges for the creative team. For this month's cover story, Jeffrey Kim, Jonathan P. Allen, and Elan Lee retell the plotline for ILB as it unfolded, detailing the design decisions and the ways players ultimately constructed and directed the game. While ILB succeeded in adding new layers and dimensions to the ARG experience and supporting technologies, the authors contend that in the end, it's all about the story.

\section{Also this month, Mandviwalla et al. EXamine municipal} wireless networks and how they represent a new option for broadband access to the Internet that promises anytime, anywhere connectivity. Alfred Loo says the strength of a computer system's security is always measured by its weakest component, and in most systems that component is the end user. Further, wireless security will never be realized without a coordinated effort among corporations, manufacturers, employers, and end users.

Shih et al. explore global IT diffusion by analyzing data from 44 countries over a 15-year period and found markedly different results for developing and developed countries. McKinney et al. investigate the professional IT experience for men and women and find significant similarities that shine new light on reasons why women are still underrepresented in the field. Marks et al. study the ways managers influence how knowledge is shared within an organization. Keane, O'Brien, and Smyth track the role of user bias in deciding which links to follow in rank-ordered results lists. And Taylor, Loiacono, and Watson discuss alternative formats for Web banner ads.

In this month's "Viewpoint," Andy Oram calls for technologists to support the Peer to Patent project, an initiative created to address the proliferation of computer-related patents that sometimes hinder innovation rather than promote it. Peer to Patent channels input directly from the public to the examiners at the U.S. Patent and Trademark Office who ultimately decide what patents to grant.

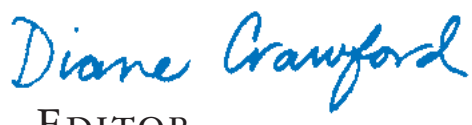

EDITOR
COMMNICATIOSS

A monthly publication of the ACM Publications Office

ACM

2 Penn Plaza, Suite 701

New York, NY 10121-0701 USA

(212) 869-7440 FAX: (212) 869-0481

\section{Group Publisher: Scott Delman \\ Editor: Diane Crawford \\ Managing Editor: Thomas E. Lambert \\ Senior Editor: Andrew Rosenbloom \\ Editorial Assistant: Zarina Strakhan \\ Copyright: Deborah Cotton}

\section{Contributing Editors}

Phillip G. Armour; Hal Berghel;

Michael A. Cusumano; Peter J. Denning;

Robert L. Glass; Seymour Goodman;

Rebecca Mercuri; Peter G. Neumann;

Pamela Samuelson; Meg McGinity Shannon

Art Director: Caren Rosenblatt Production Manager: Lynn D’Addesio

\section{Advertising}

ACM Advertising Department

2 Penn Plaza, Suite 70I, New York, NY 10I2I-070I

(2I2) 869-7440; Fax: (2I2) 869-048।

Account Executive:

William R. Kooney: acm-advertising@acm.org

For the latest media kit-including rates-contact:

Graciela Jacome: jacome@acm.org

\section{Contact Points}

CACM editorial: crawford_d@acm.org

Copyright permission: permissions@acm.org

Calendar items: calendar@acm.org

Change of address: acmcoa@acm.org

\section{Communications of the ACM}

(ISSN 000I-0782) is published monthly by the ACM, 2 Penn Plaza, Suite 70I, New York, NY I0I2I-070I. Periodicals postage paid at

New York, NY 1000I, and other mailing offices.

POSTMASTER: Please send address changes to Communications of the ACM, 2 Penn Plaza,

Suite 70I, New York, NY I0I2I-070I USA

Printed in the U.S.A.

Association for Computing Machinery

Advancing Computing as a Science \& Profession 


\section{AC The Association for Computing Machinery}

ACM (founded 1947) is an international scientific and educational organization dedicated to advancing the art, science, engineering, and application of information technology, serving both professional and public interests by fostering the open interchange of information and by promoting the highest professional and ethical standards.

\section{Executive Director and CEO: John White Director, ACM U.S. Public Policy Office: Cameron Wilson}

Deputy Executive Director and COO: Patricia Ryan Director, Office of Information Systems: Wayne Graves Director, Office of Financial Services: Russell Harris Financial Operations Planning: Darren Ramdin

Director, Office of Membership: Lillian Israel

Director, Office of Publications: Mark Mandelbaum

Deputy Director: Bernard Rous Deputy Director, Magazine Development: Diane Crawford Publisher, ACM Books and Journals: Jono Hardjowirogo

Director, Office of SIG Services: Donna Cappo

$\begin{aligned} \text { ACM Council } & \\ \text { President } & \text { Stuart I. Feldman } \\ \text { Vice-President } & \text { Wendy Hall } \\ \text { Secretary/Treasurer } & \text { Alain Chesnais } \\ \text { Past President } & \text { David A. Patterson } \\ \text { Chair, SGB Board } & \text { Joseph A. Konstan } \\ \text { Co-Chairs, Publications Board } & \text { Ronald Boisvert, } \\ & \text { Holly Rushmeier }\end{aligned}$

Members-at-Large: Michel Beauduoin-Lafon (2000-2008);

Chuang Lin (2007-2008); Bruce Maggs (2006-2010); Jennifer Rexford (2007-2008); Barbara Ryder (2000-2008); David S.

Wise (2004-2008)

SGB Council Representatives:

Norman Jouppi (2006-2007); Robert A. Walker (2006-2008);

Alexander Wolf (2005-2007)

\section{Board Chairs and Standing Committees}

Education Board: Andrew McGettrick

SGB Board: Joseph A. Konstan; Membership Services Board: Terry Coatta; Publications Board: Ronald Boisvert, Holly Rushmeier Professions Board: Stephen R. Bourne USACM Committee: Eugene Spafford

\author{
SIG Chairs \\ SIGACCESS: Vicki Hanson SIGACT: Richard Ladner; \\ SIGAda: John McCormick; SIGAPL: Guy R. Larocque; \\ SIGAPP: Barrett Bryant; SIGARCH: Douglas C. Burger; \\ SIGART: Maria Gini; SIGBED: Lothar Theile; \\ SIGCAS: Florence Appel; SIGCHI: Julie Jacko; \\ SIGCOMM: Mark Crovella; SIGCSE: Barbara Boucher Owens; \\ SIGDA: Diana Marculescu; SIGDOC: Brad Mehlenbacker; \\ SIGecom: David Pennock SIGEVO: Darrell Whitley; \\ SIGGRAPH: G. Scott Owen; SIGIR: Elizabeth Liddy; \\ SIGITE: Han Reichgelt; SIGKDD: Gregory Piatetsky-Shapiro; \\ SIGMETRICS: Carey Willliamson; SIGMICRO: Erik Altman; \\ SIGMIS: Janice Sipior; SIGMOBILE: David B. Johnson; \\ SIGMOD: Raghu Ramakrishnan; SIGMULTIMEDIA: Klara \\ Nahrstedt; SIGOPS: Doug Terry; SIGPLAN: Kathleen Fisher; \\ SIGSAC: Virgil D. Gligor; SIGSAM: Mark W. Geisbrecht; \\ SIGSIM: Simon J.E. Taylor; SIGSOFT: William G. Griswold; \\ SIGUCCS: Leila Lyons; SIGWEB: Ethan Munson
}

For information from Headquarters: (2I2) 869-7440

ACM U.S. Public Policy Office:

Cameron Wilson, Director

I 100 Seventeenth St., NW

Suite 507

Washington, DC 20036 USA

$+|-202-659-97| \mid-$ office

+ I-202-667-1066-fax

wilson_c@acm.org

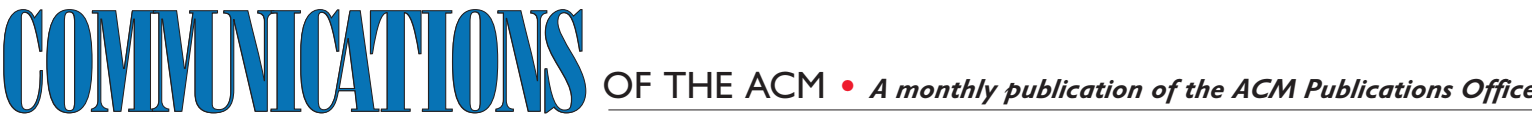

ACM, 2 Penn Plaza, Suite 70I, New York, NY I0I2I-070I USA (2I2) 869-7440 FAX: (2I2) 869-048I

\section{Editorial Advisory Board}

Gordon Bell; Hal Berghel; Grady Booch;

Nathaniel Borenstein; Vinton G. Cerf

Kilnam Chon; Jacques Cohen; Larry L. Constantine;

Jon Crowcroft; Peter J. Denning; Mohamed E. Fayad;

Usama Fayyad; Christopher Fox; Ravi Ganesan;

Don Hardaway; Karen Holtzblatt; Pattie Maes;

Eli Noam; Cherri Pancake; Yakov Rekhter;

Douglas Riecken; Ted Selker; Dennis Tsichritzis:

Ronald Vetter

\section{Publications Board}

Co-Chairs: Ronald F. Boisvert and Holly Rushmeier Board Members: Gul Agha; Michel BeaudouinLafon; Carol Hutchins; Mary Jane Irwin; Ee-ping Lim; Keith Marzullo; M. Tamer Ozsu; Vincent Shen; Mary Lou Soffa; Ricardo Baeza-Yates

\section{ACM Copyright Notice}

Copyright (C) 2008 by Association for Computing Machinery, Inc. (ACM). Permission to make digital or hard copies of part or all of this work for personal or classroom use is granted without fee provided that copies are not made or distributed for profit or commercial advantage and that copies bear this notice and full citation on the first page.
Copyright for components of this work owned by others than ACM must be honored. Abstracting with credit is permitted. To copy otherwise, to republish to post on servers, or to redistribute to lists, requires prior specific permission and/or fee. Request permission to publish from: Publications Dept. ACM, Inc. Fax + I (2I2) 869-048I or email <permissions@ acm.org>

For other copying of articles that carry a code at the bottom of the first or last page or screen display, copying is permitted provided that the per-copy fee indicated in the code is paid through the Copyright Clearance Center, 222 Rosewood Drive, Danvers, MA 01923, 508-750-8500, 508-750-4470 (fax).

\section{Subscriptions}

Annual subscription cost is included in the society member dues of $\$ 99.00$ (for students, cost is included in $\$ 40.00$ dues); the nonmember annual subscription is $\$ 189.00$ See top line of mailing label for subscription expiration date coded in four digits: the first two are year, last two, month of expiration. Microfilm and microfiche are available from University Microfilms International, 300 North Zeeb Road, Dept. PR, Ann Arbor, MI 48I06; (800) 52I-0600.
Single Copies are $\$ 8$ to members and $\$ 17$ to nonmembers. Please send orders prepaid plus $\$ 7$ for shipping and handling to ACM Order Dept., P.O. Box I |4 |4, New York, NY 10286-1414 or call (212) 626-0500. For credit card orders call (800) 342-6626. Order personnel on duty 8:30-4:30 EST. After hours, please leave message and order personnel will return your call.

Notice to Past Authors of ACM-Published Articles ACM intends to create a complete electronic archive of all articles and/or other material previously published by ACM. If you were previously published by ACM in any journal or conference proceedings prior to 1978, or any SIG newsletter at any time, and you do not want this work to appear in the ACM Digital Library, please inform permissions@acm.org, stating the title of the work, the author(s), and where and when published. 